\title{
Impedimetric analysis of interaction between DNA and phytochemical constituents' of Calotropis procera for pre-clinical evaluation
}

\author{
Seetharamaiah Nalini $i^{1,2}$, Seetharamaiah Nandini ${ }^{1,2}$, Shivayogeeswar E. Neelagund ${ }^{2 *}$, \\ Jose Savio Melo ${ }^{3^{*}}$, Gurukar Shivappa Suresh ${ }^{*}$
}

${ }^{1}$ Department of Chemistry and Research Centre, N.M.K.R.V. College for Women, Jayanagar, Bangalore 560 011, India

${ }^{2}$ Department of PG Studies and Research in Biochemistry, Jnana Sahyadri, Kuvempu University,

Shankaraghatta 577 451, Shivamogga, Karnataka, India

${ }^{3}$ Nuclear Agriculture and Biotechnology Division, Bhabha Atomic Research Centre, Mumbai 400085, India

*Corresponding author: Tel: 91-80-26654920; Fax: 91-80-22453665; E-mail: sureshssmrv@ yahoo.co.in;

jsmelo@barc.gov.in; neelgund@gmail.com

Received: 18 December 2016, Revised: 20 March 2017 and Accepted: 07 April 2017

DOI: $10.5185 /$ amlett.2017.1554

www.vbripress.com/aml

\begin{abstract}
In this report, extractions of the Calotropis procera polyphenols have been carried out in conventional soxhlet assisted extraction (SAE) and it is compared with microwave assisted extraction (MAE). As an extension of our previous work reported, we attempted to study the electrochemical interaction of the aqueous plant extract with DNA modified electrode Gr/PAH/NTG/PPy/DNA. The binding constant $K_{\mathrm{f}}$ determined using UV-Vis spectroscopy was found to be $4.91 \times 10^{-1}$ and $4.55 \times 10^{-1} \mu \mathrm{mol}$ $\mathrm{dm}^{-3}$ for soxhlet assisted plant extract (SAPE) and microwave assisted plant extract (MAPE) respectively. This was consistent with the electrochemical determination of $K_{\mathrm{f}} 4.31 \times 10^{-6}$ and $4.71 \times 10^{-4} \mu \mathrm{mol} \mathrm{dm}^{-3}$ for SAPE and MAPE respectively. Further the surface coverage area $\left(\Gamma_{\mathrm{s}}\right)$ of the electrode fabricated using DNA was calculated using Chronocoulometry for the plant extracts. The linear range of the aqueous extract on the Gr/PAH/NT-G/PPy/DNA modified electrode was found to be from 1-250 $\mu$ mol $\mathrm{dm}^{-3}$, with a limit of detection of 0.22 and $0.29 \mu \mathrm{mol} \mathrm{dm}^{-3} \mathrm{~mL}^{-1}$ for SAPE and MAPE respectively. The limit of quantification was found to be 0.68 and $0.88 \mu \mathrm{mol} \mathrm{dm} \mathrm{mL}^{-1}$ for SAPE and MAPE respectively. As a result Calotropis procera can be studied further to applied for anticancer activity. Moreover, electrochemical methods can be a promising technique in drug analysis. Copyright @ 2017 VBRI Press.
\end{abstract}

Keywords: Impedimetric detection, soxhlet assisted extraction, microwave assisted extraction, chronocoulometry, spectrophotometry.

\section{Introduction}

Deoxyribonucleic acid (DNA) is a genetic material which carries hereditary information. It plays a crucial part as selective template for the construction of tRNA (transfer ribonucleic acid), mRNA (messenger ribonucleic acid) and rRNA (ribosomal ribonucleic acid) [1]. DNA is also important in discovery of anticancer drugs because the chemicals bind and interact with DNA leading to specific changes. The interaction of the chemicals with DNA is based on three mechanisms (i) intercalating between stacked base pairs, (ii) noncovalent groove binding, or (iii) electrostatic bind to the negatively charged nucleic acid sugar phosphate skeleton $[\mathbf{2}, \mathbf{3}]$.

The anticancer drugs basically interact with nucleic acids, specific enzymes, microtubules and hormone/ growth factor receptors. When, these drugs intermingle with nucleic acids it results in DNA damage leading to the cell death. The electrochemical detection of anti-cancer activity on DNA based biosensors depends on some as mentioned essential facts- the one is the differentiation in the redox activities of the nucleic acid and anticancer molecules in the presence or absence of DNA. The second is the change in the formal potential of the redox pair and the peak current decrease which may be due to the considerable decline in the diffusion after interaction with DNA [4]. The use of DNA biosensors are not only restricted to the study of anticancer activity, there are also wide applications of DNA biosensors reported for the determination of water, food, soil etc. [5].

The electrochemical study of drug and DNA interaction has been an interested topic of research since 1989. The first report of interaction of DNA with metal complexes was reported by Bard et al. [6]. The electrochemical detection of interactions of cisdiaminedichloroplatinum(II) and cis-bis(3-aminoavone) dichloroplatinum(II) (cis-BAFDP) with calf thymus 
double-stranded DNA (dsDNA) was studied by Erdem and co-workers [7]. Similarly, the interaction of DNA with lycorine - an alkaloid found in various Amaryllidaceae species has also been reported [8]. Mitoxantrone [9], doxorubicin [10], a series of Mannich bases [11] an imidazoacridinone derivative, Symadex [12] are some of the literature reports based on electrochemical detection of interaction of drugs with DNA.

Plants play an important role in treatment of various diseases. The utilization of plants against diseases has been prepared and piled up by Chinese emperor Shen Nung in 2,800 BC [13]. Plants can also be used for cancer treatment. It posses certain compounds which have medicinal values and these compounds cannot be synthesized in laboratories. The anticancer mechanism of the plant has an adverse effect on the cytoskeletal proteins, inhibit DNA topoisomerase and antiprotease, and stimulate immune system [14]. There are innumerable reports of isolating anticancer compounds from plants such as Apigenin derived from parsley is known to be active against cancer cell lines (MCF 7), colon cell line (HCT 116) [15]. Diferuloylmethane from Curcuma longa demonstrates anti-cancer effects for colon cancer, breast cancer [16], lung metastases, and brain tumor [17]. Calotropis procera known as Arka have many medicinal properties and we have compiled in [18]. Briefly, the various parts of plant is used in the treatment of diseases like leprosy, eczema, inflammation, cutaneous infections, syphilis, malarial and low hectic fevers, and as a botifacient, rheumatism, as an anti-inflammatory and antimicrobial, malaria etc.,[19] It is a plant grown in tropical and subtropical regions. Apart from the medicinal properties it also posses unique properties like its wood is economical as fuel, latex is used in tanning industry and also used as an abortifacient. [20]

The extraction of the bioactive constituents of the medicinal plants is a most important factor. The conventional method of extractions includes solvent extractions utilizing huge quantities of solvents that are refluxed for several hours are a troublesome. While, the Microwave assisted extraction is one of promising extraction technique replacing the existing conventional mode. The attracting feature of the former technique is diminishing the time and solvent utilization, an enhancement in the quality of the extraction [21, 22].

Whereas, the electrochemical impedance spectroscopy is a powerful method to determine the electric resistance and electrode surface modification phenomenon. It is also used to detect the interaction of the analyte with the immobilizing matrix on the electrode [23]. Impedance spectroscopy is examined at different frequencies which allow characterization of electrodes using an equivalent circuit [24]. It is extensively used in biosensor research, due its uncomplicated and detailed output of results compared to other electrochemical techniques [25]. This work suggests that impedimetric analysis can also be utilized to detect the drug screening.

Carbon nanotubes (CNTs) are cylindrical fullerene discovered by Sumio Iijima in 1990. CNTs are nothing but carbon allotropic form in which the graphene sheets are wrapped forming cylindrical structures with as less than 1 $\mathrm{nm}$ to several micrometers $[\mathbf{2 6}, \mathbf{2 7}$. Yangaung Li et al., have reported Nanotube-Graphene composite (NT-G) an electro-catalyst based on oxidation condition of CNTs which leads to the limited removal of the outer walls in which the nanoscale graphene sheets are attached to the inner wall of the CNTs [28]. These electro-catalysts when applied in biosensors increase the electrocatalytic activity of biosensors.

Polymer/CNT nanotube composites have attracted much attention in the research field. Particularly, Polypyrrole (PPy)/CNTs combination is receiving much interest because it maintains an excellent accolades, as they have outstanding electrical conductance, excellent magnetic properties and superior thermal stability [29]. Conducting PPy can be formed by the oxidization of Pyrrole [30]. It has been reported the use of PPy in the applications of biosensors, DNA sensors, actuators, immunosensors, drug delivery, photoelectrochemical devices etc. has been reported in a good number of literature [31-33].

We have previously reported the electrochemical prescreening of anticancer activity of the Calotropis procera plant extract towards LN-18 and DNA modified electrode [18]. In this study, we have extracted the phytochemicals constituents of Calotropis procera by Microwave method and the conventional Soxhlet extraction method. This is the first report on imedimetric analysis of plant extract with DNA. The advantages of this method are easy and precise analysis. The principle of the present work is based on the impedimetric data obtained at potentials $0.3,1.0$ and $1.4 \mathrm{~V}$ towards the interaction between DNA and the plant extract as a result, the real part of the impedance tend to decrease as the concentration of the extract increase until saturation is achieved. The decrease can be ascribed to the intercalating of the plant extract with DNA. The advancements in the current work are- (a) impedimetric analysis of DNA and plant extract interaction, (b) charge transfer resistance of DNA has been studied, (c) the amount of plant extract adsorbed on DNA modified electrode is determined using Chronocoulometry(CC) and (d) the binding constant also been examined using spectrophotometry and is compared with electrochemical method. We have also studied the effect of $\mathrm{pH}$ and temperature $\left(T_{\mathrm{m}}\right)$ on the DNA electrode in presence of plant phytochemicals constituents. The performance of the DNA biosensor and the effect of the soxhlet assisted plant extract and Microwave assisted plant extract aqueous extracts are discussed.

\section{Experimental}

\section{Reagents and materials}

DNA from herring sperm was procured from HiMedia, Mumbai, India. MWCNTs and poly(allylamine hydrochloride) (PAH) were obtained from Sigma aldrich. Tris $\mathrm{HCl}$, Gallic acid, Folin ciocalteu (FC) reagents were purchased from Loba Chemie, Mumbai, India. Pyrrole was obtained from Spectrochem, Mumbai, India. Magnesium chloride was procured from Qualigens, Mumbai, India. Ethyl aceteate, Potassium permanganate and silica thin layer chromatography (TLC) plates were obtained from 


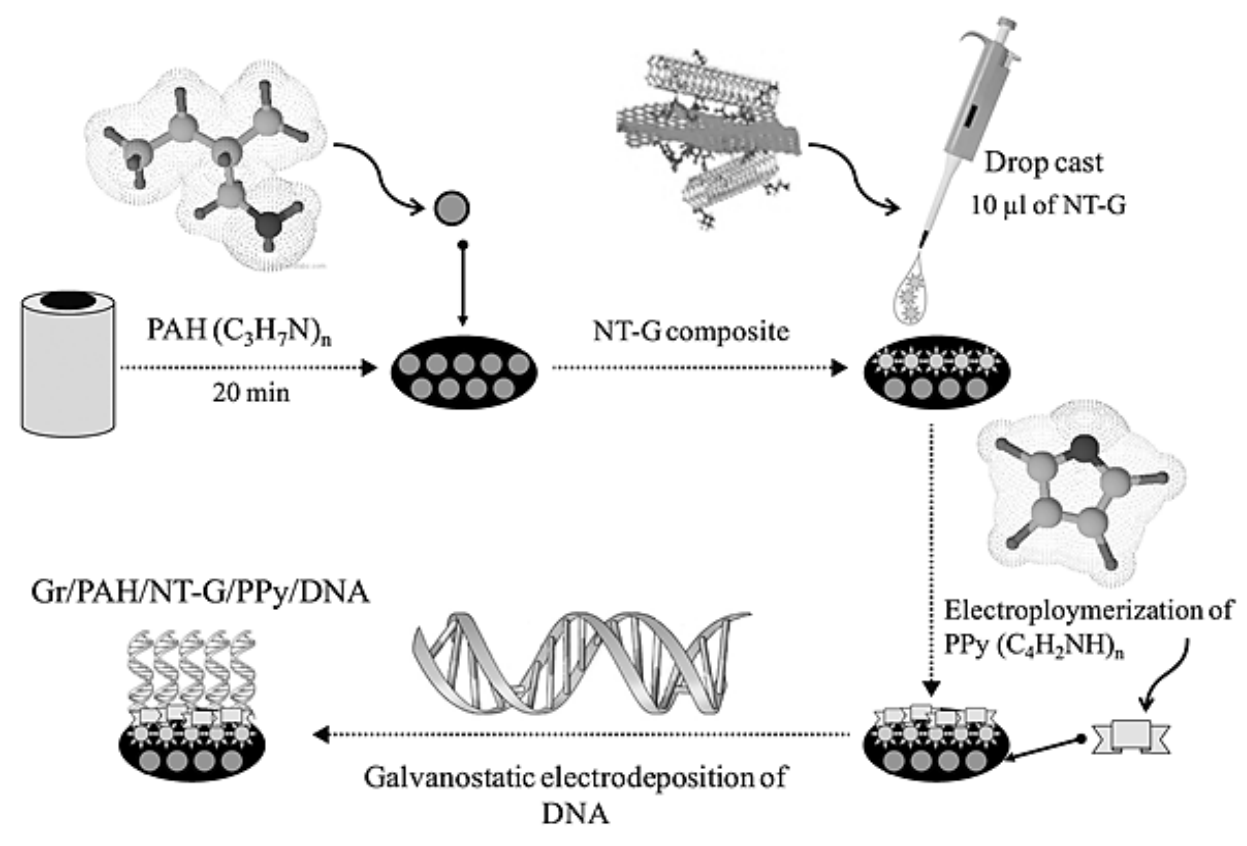

Fig. 1. Schematic representation of preparation of electrode.

Merck, USA. Sodium bi carbonate, Methanol was procured from NICE chemicals, Kerala, India. Sulphuric acid was procured from RANKEM, Faridabad, India. PK3 electrode polishing kit was obtained from BAS Inc. Tokyo, Japan. Phosphate buffer saline was prepared from stock solution of $0.1 \mathrm{~mol} \mathrm{dm}{ }^{-3} \mathrm{KH}_{2} \mathrm{PO}_{4}, 0.1 \mathrm{~mol} \mathrm{dm}^{-}$ ${ }^{3} \mathrm{~K}_{2} \mathrm{HPO}_{4}$ and $0.1 \mathrm{~mol} \mathrm{dm}{ }^{-3} \mathrm{KCl} \mathrm{pH}$ was adjusted using 0.5 mol dm${ }^{-3} \mathrm{HCl}$ and $0.5 \mathrm{~mol} \mathrm{dm}^{-3} \mathrm{NaOH}$. All other chemicals used were of analytical reagent grade unless otherwise mentioned and used without further purification. All solutions were prepared with pure water.

\section{Electrochemical measurements}

All electrochemical experiments were carried out with Versa stat 3 (Princeton Applied Research, USA) except Chronocoulometry experiment which was performed in CHI Instruments, USA. Temperature measurements were carried out using Equitron ${ }^{\circledR}$, digital temperature controller equipped with stirred water bath. The UV studies were carried out in Shimadzu UV-1700 spectroscopy. All experiments were done in a conventional three electrode electrochemical cell with bare $\mathrm{Gr}$ or DNA modified electrode as working electrode, saturated calomel electrode (SCE) as reference electrode and platinum wire as auxiliary electrode.

\section{Extraction of phytochemicals constituents}

The plant material was collected, identified and stored in accordance with the help of taxonomical experts. The soxhlet assisted extraction of the phytochemical constituents is as reported in our previous work [18]. Soxhlet extractions were performed using $50 \mathrm{~g}$ of powdered plant to which $50 \mathrm{ml}$ of water was added. The mixture was transferred to cellulose extraction thimble and inserted into soxhlet assembly containing $500 \mathrm{ml}$ round bottomed (RB) flask. $250 \mathrm{~mL}$ of water was added into the
$\mathrm{RB}$ and the whole assembly was heated for about $48 \mathrm{hrs}$ at $50{ }^{\circ} \mathrm{C}$ and filtered. The obtained product is given as SAE. The mixture with same contents were taken in a beaker and placed in a closed domestic microwave oven and irradiated for $160 \mathrm{~W}$ with constant stirring for $10 \mathrm{~min}$ of irradiation. This was repeated for 1 hour until the MAE plant extract spot matched with the SAE plant extract in TLC. A comparative study of the conventional method of SAE and the present MAE is tabulated in Table 1 [34-37].

Table 1.

\begin{tabular}{lcc}
\hline \multicolumn{1}{c}{ Extraction technique } & Time Required & Reference \\
\hline Soxhlet assisted extraction & 2 weeks & {$[\mathbf{3 4 ]}$} \\
Soxhlet assisted extraction & $18-20 \mathrm{~h}$ & {$[\mathbf{3 5 ]}$} \\
Soxhlet assisted extraction & $24 \mathrm{~h}$ & {$[\mathbf{3 6}]$} \\
Soxhlet assisted extraction & $72 \mathrm{~h}$ & {$[\mathbf{3 7 ]}$} \\
Soxhlet assisted extraction & $48 \mathrm{~h}$ & {$[\mathbf{1 8}]$} \\
Microwave assisted extraction & $1 \mathrm{~h}$ & This work \\
\hline
\end{tabular}

Different types of solvent system for TLC were used $[38,39]$ the most suitable was found to be $\mathrm{C}_{4} \mathrm{H}_{8} \mathrm{O}_{2}$ : $\mathrm{CH}_{4} \mathrm{O}$ : $\mathrm{H}_{2} \mathrm{O}(5: 1.2: 0.8)$ [40]. The plant extract (PE) of SAE and MAE is denoted as SAPE and MAPE. The filtered extract solutions were filled in air tight bottles and stored in refrigerator which was further used for the electrochemical detection of anticancer properties. The total polyphenol content present in the plant extract was determined using Folin-Ciocalteu (F-C) method. This method is based on the reaction of phenolic compound with colorimetric reagent. The $\mathrm{F}-\mathrm{C}$ assay depend on the transfer of electrons in alkaline medium from phenolic compounds to phosphomolybdic/phosphotungstic acid complexes to form blue complexes that are determined spectroscopically at approximately $760 \mathrm{~nm}$ [41]. Results were expressed as $\mathrm{mg}$ Gallic acid equivalents per liter of SAPE (mg GAE/L). The TPC present in the sample of $20 \mu \mathrm{L}$ of SAPE and 
MAPE was found to be $500 \mathrm{mg}$ and $475 \mathrm{mg}$ GAE/L respectively.

\section{Preparation of the DNA modified electrode}

The preparation of the modified electrode is as our previously reported work [18]. An electrode was prepared by drilling a Teflon bar to $0.5 \mathrm{~mm}$ diameter and introducing a Gr cylinder into it. Electrical contact was made with a copper wire through the centre of the Teflon bar. Before modification, the Gr electrode was polished to get a mirror shining surface by means of PK-3 electrode polishing kit which consists of $1 \mu \mathrm{m}$ aqueous polishing diamond and $0.05 \mu \mathrm{m}$ polishing alumina. It was then ultrasonicated for several minutes and rinsed with pure water. The dried $\mathrm{Gr}$ electrode was wrapped with $\mathrm{PAH}$ a polycation by dipping the electrode in the PAH solution for about $20 \mathrm{~min}$. To this $10 \mu \mathrm{L}$ of NT-G composite was drop-casted onto the $\mathrm{Gr} / \mathrm{PAH}$ electrode surface to obtain Gr/PAH/NT-G. The electro-polymerization of PPy was carried out at a potential range from -0.3 to $0.80 \mathrm{~V}$ (versus SCE) at a scan rate of 50 $\mathrm{mVs}^{-1}$ for 20 cycles. Thus Gr/PAH/NT-G/PPy obtained electrode was washed gently with water to remove unabsorbed particles. Galvanostatic electrodeposition was implemented for immobilization of DNA. The electrode plate when exposed to ammonia vapor, yellow spots was observed which was further confirmed under UV-light. The $R_{f}$ value of the plant extract of both SAE and MAE matched approximately and it was found to be about 1.68 and $1.48 \mathrm{~cm}$ respectively. The phytochemicals evaluation for the presence of alkaloids, flavonoids, saponins, steroids, tannins, triterpenoids, phenols, Anthraquinones, proteins, quinones in the aqueous extract was performed using standard protocols as described elsewhere [42, 43].The results revealed that the aqueous extract of SAE and MAE contains falvonoids, saponins, steroids and anthraquinones.

Anticancer drugs interact with DNA preventing the proper relaxation of DNA. The discovery of anticancer drugs requires a characterization in which the compounds can target DNA. Clinically DNA binding compounds corresponds to anticancer molecules which can take part either by binding or by modifying the DNA [44]. EIS measurements were made in a PBS solution containing $\mathrm{Gr} / \mathrm{PAH} / \mathrm{NT}-\mathrm{Gr} / \mathrm{PPy} / \mathrm{DNA}$ as a working electrode, with platinum and calomel as auxiliary and reference electrode respectively using increasing concentrations of plant phytochemical constituents. The effect of the increasing concentration of PE on the biosensor was studied at three

Table 2. The data obtained from the simulation of impedance responses at the DNA modified electrode in presence and absence of SAPE and MAPE ${ }^{\dagger}$ at potential of $0.3 \mathrm{~V}$.

\begin{tabular}{|c|c|c|c|c|c|c|c|c|c|}
\hline $\begin{array}{l}\text { Conc. of SAPE } \\
\text { and } \mathrm{MAPE}^{\dagger} \text { in } \mu \mathrm{L}\end{array}$ & $\begin{array}{l}R_{\mathrm{s}} \\
(\Omega)\end{array}$ & $\begin{array}{c}Q_{1} \\
\left(\mu F \mathrm{~cm}^{-2}\right)\end{array}$ & $Q-\mathrm{n}$ & $\begin{array}{r}R_{1} \\
(\Omega)\end{array}$ & $\begin{array}{c}Q_{2} \\
\left(\mu F \mathrm{~cm}^{-2}\right)\end{array}$ & $Q-\mathrm{n}$ & $\begin{array}{l}R_{2} \\
(\Omega)\end{array}$ & $\begin{array}{l}C_{1} \\
(\mathrm{n} F)\end{array}$ & $\begin{array}{l}R_{3} \\
(\Omega)\end{array}$ \\
\hline \multirow[t]{2}{*}{0} & 122.6 & 0.0022 & 1 & 47.89 & 572.2 & 0.6 & 8.098 & 0.0006 & $1.372 \times 10^{4}$ \\
\hline & $(250)$ & $(0.001)$ & (1) & (1.39) & $(387)$ & $(0.5)$ & $(0.068)$ & $(0.0006)$ & $\left(3.07 \times 10^{11}\right)$ \\
\hline \multirow[t]{2}{*}{50} & 125 & 0.0025 & 0.7 & 80.98 & 408.2 & 0.9 & 4.789 & 0.0012 & $6.40 \times 10^{4}$ \\
\hline & $(255)$ & (1.199) & $(0.8)$ & (1.59) & $(303.7)$ & $(0.8)$ & $(0.060)$ & $(0.0012)$ & $\left(2.83 \times 10^{18}\right)$ \\
\hline \multirow[t]{2}{*}{100} & 126.3 & 0.0025 & 1 & 103.2 & 347.1 & 0.6 & 1.421 & 0.001 & $1.37 \times 10^{4}$ \\
\hline & $(257)$ & $(0.003)$ & $(0.7)$ & (1.89) & $(286.3)$ & $(0.7)$ & $(0.036)$ & $(0.001)$ & (392) \\
\hline \multirow[t]{2}{*}{150} & 129.5 & 3000 & 0.7 & 136 & 297.1 & 0.7 & 1.421 & 0.0015 & $2.58 \times 10^{12}$ \\
\hline & (258) & $(0.002)$ & $(0.6)$ & $(2.92)$ & $(234.5)$ & (1) & $(0.011)$ & $(0.0015)$ & $\left(3.62 \times 10^{12}\right)$ \\
\hline \multirow[t]{2}{*}{200} & 132.9 & 0.0025 & 1 & 170 & 297.1 & 0.6 & 1.032 & 0.001 & $1.67 \times 10^{4}$ \\
\hline & (259) & $(0.002)$ & $(0.7)$ & $(3.47)$ & $(230.8)$ & $(0.8)$ & $(0.010)$ & $(0.0014)$ & $(292.2)$ \\
\hline \multirow[t]{2}{*}{250} & 138 & 0.0027 & 1 & 200 & 273.5 & 1 & 0.316 & 0.0014 & $7.4 \times 10^{13}$ \\
\hline & $(262)$ & $(0.002)$ & $(0.7)$ & $(5.34)$ & (129.3) & (1) & $(0.001)$ & 0.0001 & (122) \\
\hline
\end{tabular}

${ }^{\dagger}$ EIS fitting data corresponding to MAPE is given within the brackets for each concentration and circuit components.

was kept at $-4{ }^{\circ} \mathrm{C}$ for overnight incubation. The as obtained electrode is denoted as Gr/PAH/NT-G/PPy/DNA throughout this manuscript. The schematic representation of the electrode is as shown in Fig. 1. The electrochemical studies were carried out at room temperature with PBS (pH 7). The physical characterization of the modified electrodes using SEM and EDAX has been described in our previous work [18].

\section{Results and discussion}

The extracted samples were applied to TLC plates in a mixture of $\mathrm{C}_{4} \mathrm{H}_{8} \mathrm{O}_{2}: \mathrm{CH}_{4} \mathrm{O}: \mathrm{H}_{2} \mathrm{O}$ (5:1.2:0.8). The dried TLC different potentials as studied by Brett et al., [45] before the guanine oxidation peak $(0.3 \mathrm{~V})$, between guanine and adenine oxidation peaks $(1.0 \mathrm{~V})$ and after adenine oxidation $(1.4 \mathrm{~V})$. Fig. 2 illustrates the nyquist plots between the real part of impedance vs. imaginary part obtained for gradual increase in PE's (both SAPE and MAPE). The data obtained by fitting the EIS measurements to an equivalent circuit is shown in the inset of Fig. 2 and from the corresponding data tabulated in Table 2-4, it can be seen that as the concentration of PEs increase the $R_{\mathrm{ct}}$ also increases. Further it can be noticed that, the addition of PE did not change the shape of the nyquist plot but there was a decrease in their radii. The 
behavior of the PEs at $0.3 \mathrm{~V}, 1.0 \mathrm{~V}$ and $1.4 \mathrm{~V}$ has similar effect indicating the efficient anticancer property.
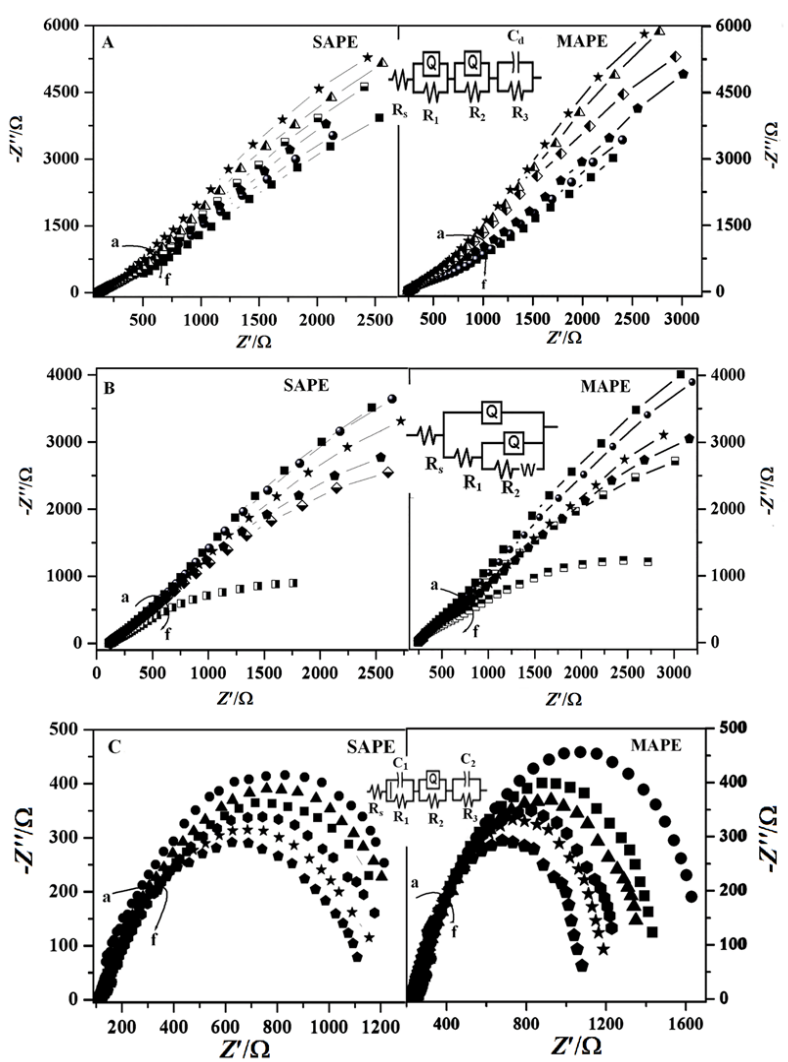

Fig. 2. Complex impedance plots obtained at increasing concentration of (a-f; 0-250 $\mu \mathrm{mol} \mathrm{dm}^{-3}$ ) SAPE and MAPE at (A) $0.3 \mathrm{~V}$, (B) $1.0 \mathrm{~V}$ and (C) $1.4 \mathrm{~V}$ potentials. Inset figures are the equivalent circuits used for analysis of complex impedance plots.

The equivalent circuit measured at $0.3 \mathrm{~V}$ obtained for the increasing concentrations of PEs exhibits a $R_{\mathrm{S}}\left(Q_{1} R_{1}\right)\left(Q_{2} R_{2}\right)\left(C R_{3}\right) \quad$ model. The electrochemical parameters are as shown in Table 2 the $R_{\mathrm{S}}$ value has negligible increase because of the increasing concentration of $\mathrm{PE}$ in the electrolyte which relates to the ohmic resistance. The $R_{\mathrm{ct}}$ or $R_{1}$ also exhibits an increase due to the binding of phytochemicals constituents to immobilized DNA biosensor producing an intercalation effect that decreases the charge transfer resistance of the PE. $Q_{1}$ is the constant phase element which distributes the capacitance between the electrode/electrolyte interfaces. The $Q_{2}$ and $R_{2}$ can be attributed to the binding of the PEs that liberates reactive oxygen species (ROS). The $R_{2}$ shows a decrease in value which may be due to the binding of more number of ROS on to the DNA biosensor leading to depletion of the resistance. The $C$ and $R_{3}$ are the capacitance and resistor evolved may be due to the presence of non-conducting DNA biomolecule. The CPE's $\left(Q_{1} \& Q_{2}\right)$ decrease upon increase in PE which can be attributed to the binding of the active polyphenol molecules of PEs bind to DNA surfaces dropping the capacitance values. The 'n' values of $Q_{1}$ and $Q_{2}$ varies from 0.5 to 1 which indicates that the DNA on the electrode surface acts as diffusion layer. The association constant was calculated according to the literature [46] to determine the interaction of PE's and DNA biosensor.

$K_{\mathrm{a}} C=\frac{R_{\mathrm{ct}}\left(C_{\mathrm{i}}\right)-R_{\mathrm{ct}}\left(C_{\mathrm{O}}\right)}{R_{\mathrm{ct}}\left(C_{\mathrm{o}}\right)}=\frac{\Delta R_{\mathrm{ct}}-\left(C_{\mathrm{i}}\right)}{R_{\mathrm{ct}}\left(C_{\mathrm{o}}\right)}$

Where $K_{\mathrm{a}}$ is association constant, $R_{\mathrm{ct}}\left(C_{\mathrm{i}}\right)$ and $R_{\mathrm{ct}}\left(C_{0}\right)$ are charge transfer resistance of DNA with and without PEs. A plot of $\Delta R_{\mathrm{ct}}\left(C_{\mathrm{i}}\right) / R_{\mathrm{ct}}\left(C_{0}\right)$ vs concentration of PEs was plotted [Fig. 3 (a) for SAPE and inset for MAPE] and it was shown that the $\Delta R_{\mathrm{ct}}\left(C_{\mathrm{i}}\right) / R_{\mathrm{ct}}\left(C_{0}\right)$ increase with increasing concentration of PEs. The linear regression equation follows as

$\frac{\Delta R_{\mathrm{ct}}-\left(C_{\mathrm{i}}\right)}{R_{\mathrm{ct}}\left(C_{\mathrm{o}}\right)}$

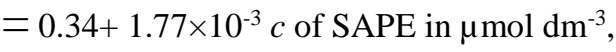

$R=0.980$

$\frac{\Delta R_{\mathrm{ct}}-\left(C_{\mathrm{i}}\right)}{R_{\mathrm{ct}}\left(C_{\mathrm{o}}\right)}$

$=-0.70+2.12 \times 10^{-2} c$ of MAPE in $\mu \mathrm{mol} \mathrm{dm}{ }^{-3}$,

$R=0.972$

The $K_{\mathrm{a}}$ was calculated from the slope of regression equation and it was found to be $1.77 \times 10^{-3}$ and $2.12 \times 10^{-2}$ $\mu \mathrm{mol} \mathrm{dm}^{-3}$ for SAPE and MAPE respectively. Typical Nyquist plots obtained at $1.0 \mathrm{~V}$ after 30 min incubation under various concentrations of PE's are shown in Fig. 2(B) The parameters obtained by fitting the equivalent circuit and the calculated inhibited efficiency are listed in Table 3. The circuit model is $R_{\mathrm{s}}\left(Q_{1}\left(R_{1}\left(Q_{2}\left(R_{2} W\right)\right)\right)\right)$. The circuit component has its own usual meaning. The increase in PEs concentration leads to increase of $R_{\mathrm{S}}, R_{1}$ and $R_{2}$. The $Q_{1}$ decreases upon subsequent addition of PE. The $\mathrm{n}$ values of CPEs are close to 1.0 indicating the double layer capacitors are porous. The presence of Warburg impedance component in circuit can be a sign of limitation of mass transfer by the ROS layer formed on the DNA modified electrode surface. The association constant was calculated as in equation (1) and was found to be $1.57 \times 10^{-3}$ and $2.71 \times 10^{-3} \mu \mathrm{mol} \mathrm{dm}{ }^{-3}$ for SAPE and MAPE respectively. The linear regression equation obtained from the Fig. 3 (b) and inset is as follows:

$$
\begin{aligned}
& \frac{\Delta R_{\mathrm{ct}}-\left(C_{\mathrm{i}}\right)}{R_{\mathrm{ct}}\left(C_{\mathrm{o}}\right)}
\end{aligned}
$$

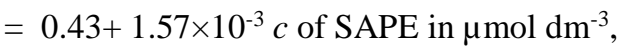

$$
\begin{aligned}
& R=0.976 \\
& \frac{\Delta R_{\mathrm{ct}}-\left(C_{\mathrm{i}}\right)}{R_{\mathrm{ct}}\left(C_{\mathrm{o}}\right)} \\
& =0.20+2.71 \times 10^{-3} c \text { of MAPE in } \mu \mathrm{mol} \mathrm{dm}{ }^{-3} \text {, } \\
& R=0.972
\end{aligned}
$$



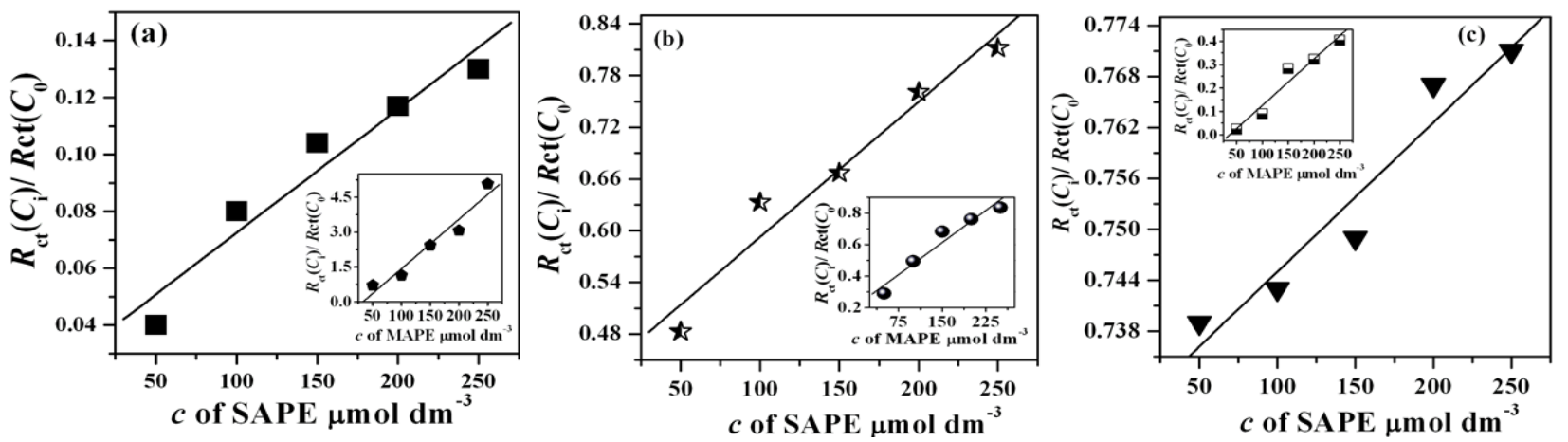

Fig. 3. Data curve obtained for $R_{\mathrm{ct}}$ data at increasing concentrations of SAPE and inset for MAPE at (A) $0.3 \mathrm{~V}$, (B) $1.0 \mathrm{~V}$ and (C) $1.4 \mathrm{~V}$ potentials.

Table 3. The data obtained from the simulation of impedance responses at the DNA modified electrode in presence and absence of SAPE and MAPE at potential of $-1 \mathrm{~V}$.

\begin{tabular}{|c|c|c|c|c|c|c|c|c|}
\hline $\begin{array}{l}\text { Conc. of PE } \\
\text { and } \mathrm{MAPE}^{\dagger} \text { in } \mu \mathrm{L}\end{array}$ & $\begin{array}{r}R_{\mathrm{s}} \\
(\Omega)\end{array}$ & $\begin{array}{c}Q_{1} \\
\left(\mu F \mathrm{~cm}^{-2}\right)\end{array}$ & $Q-\mathrm{n}$ & $\begin{array}{r}R_{1} \\
(\Omega)\end{array}$ & $\begin{array}{c}Q_{2} \\
\left(\mathrm{~m} F \mathrm{~cm}^{-2}\right)\end{array}$ & $Q$-n & $\begin{array}{r}R_{2} \\
(\Omega)\end{array}$ & $\begin{array}{l}W \\
(\Omega)\end{array}$ \\
\hline \multirow[t]{2}{*}{0} & 120 & 0.0025 & 1 & 176 & 0.51 & 0.5 & 0.016 & 3866 \\
\hline & (249) & $(0.0015)$ & (1) & $(165)$ & $(0.29)$ & $(0.5)$ & $(0.010)$ & $\left(2.35 \times 10^{9}\right)$ \\
\hline \multirow[t]{2}{*}{50} & 122 & 0.0058 & 1 & 342 & 0.14 & 0.7 & 0.025 & $2609 \times 10^{-4}$ \\
\hline & $(252)$ & $(0.1526)$ & (1) & (233) & $(0.30)$ & $(0.6)$ & $(0.011)$ & $\left(1.28 \times 10^{10}\right)$ \\
\hline \multirow[t]{2}{*}{100} & 126 & 0.0026 & 0.9 & 482 & 0.35 & 0.6 & 0.036 & $1.92 \times 10^{5}$ \\
\hline & $(257)$ & $(0.0015)$ & (1) & (327) & $(0.87)$ & $(0.7)$ & $(0.017)$ & $\left(0.27 \times 10^{-3}\right)$ \\
\hline \multirow[t]{2}{*}{150} & 128 & 0.5132 & 0.8 & 531 & 0.28 & 0.8 & 0.040 & 1593 \\
\hline & $(260)$ & $(0.0015)$ & (1) & $(522)$ & $(0.42)$ & $(0.9)$ & $(0.040)$ & $\left(0.30 \times 10^{-3}\right)$ \\
\hline \multirow[t]{2}{*}{200} & 130 & 0.2842 & 1 & 740 & 0.17 & 0.7 & 0.090 & $1765 \times 10^{-3}$ \\
\hline & $(260)$ & $(0.0026)$ & (1) & $(694)$ & $(0.33)$ & $(0.6)$ & $(0.050)$ & $\left(3.05 \times 10^{-7}\right)$ \\
\hline \multirow[t]{2}{*}{250} & 132 & 0.2743 & 1 & 970 & 0.25 & 0.6 & 0.11 & $9.84 \times 10^{-5}$ \\
\hline & (261) & $(0.0014)$ & (1) & $(975)$ & $(0.15)$ & $(0.7)$ & $(0.060)$ & $\left(1.49 \times 10^{-3}\right.$ \\
\hline
\end{tabular}

${ }^{\dagger}$ EIS fitting data corresponding to MAPE is given within the brackets for each concentration and circuit components.

The semi-circle obtained by applying at $1.4 \mathrm{~V}$ potential in Fig. 2 (C) is due to the diminutive amount of oxygen progression at the electrode surface. This can be explained due to the presence of oxygen that behaves as an electron acceptor and mediates the electrochemical process. As the progression of the chemical reaction takes place the oxygen evolved gets consumed in the vicinity of the electrode surface. The circuit obtained at this potential was $R_{\mathrm{s}}\left(C_{1} R_{1}\right)\left(Q \mathrm{R}_{2}\right)\left(\mathrm{C}_{2} \mathrm{R}_{3}\right)$. The circuit parameters are as shown in Table 4. As discussed above, the EIS results also

Table 4. The data obtained from the simulation of impedance responses at the DNA modified electrode in presence and absence of SAPE and MAPE at potential of $-1.4 \mathrm{~V}$

\begin{tabular}{ccccccccc}
\hline $\begin{array}{c}\text { Conc. of SAPE in } \\
\text { and MAPE }\end{array}$ & $\begin{array}{c}R_{\mathrm{s}} \\
(\Omega)\end{array}$ & $\begin{array}{c}C_{1} \\
(\mathrm{~m} F)\end{array}$ & $\begin{array}{c}R_{1} \\
(\Omega)\end{array}$ & $\begin{array}{c}Q \\
\left(\mathrm{~m} F \mathrm{~cm}^{-2}\right)\end{array}$ & $\mathrm{n}$ & $\begin{array}{c}R_{2} \\
(\Omega)\end{array}$ & $\begin{array}{c}C_{2} \\
(\mathrm{nF})\end{array}$ & $\begin{array}{c}R_{3} \\
(\Omega)\end{array}$ \\
\hline \multirow{2}{*}{0} & 125.2 & 0.158 & 49.75 & 0.3761 & 0.7 & 1 & 2.56 & 691 \\
& $(257.2)$ & $(0.835)$ & $(62.88)$ & $(0.1697)$ & $(0.7)$ & $(0.01)$ & $(0.156)$ & $(1101)$ \\
50 & 125.6 & 2.201 & 191.3 & 0.2305 & 0.7 & 100 & 2.52 & 430 \\
& $(259.4)$ & $(0.723)$ & $(64.45)$ & $(0.1801)$ & $(0.8)$ & $(0.03)$ & $(0.014)$ & $(1173)$ \\
100 & 127.4 & 2.202 & 194.3 & 0.2281 & 0.7 & 10 & 2.57 & 405 \\
& $(257.2)$ & $(0.721)$ & $(69.16)$ & $(0.1706)$ & $(0.7)$ & $(10)$ & $(1.421)$ & $(1357)$ \\
150 & 131 & 2.178 & 198.8 & 0.231 & 0.7 & 1000 & 2.52 & 372 \\
& $(264)$ & $(0.597)$ & $(87.77)$ & $(0.1641)$ & $(0.8)$ & $(10)$ & $(1.448)$ & $(1131)$ \\
200 & 132.5 & 2.917 & 214 & 0.2355 & 0.7 & 100 & 2.51 & 505 \\
& $(265)$ & $(0.120)$ & $(92.98)$ & $(0.1881)$ & $(0.8)$ & $(100)$ & $(1.462)$ & $(955.4)$ \\
250 & 137 & 2.467 & 218 & 0.2236 & 0.8 & 10 & 2.46 & 458.4 \\
& $(268.1)$ & $(0.122)$ & $(106.7)$ & $(0.212)$ & $(0.8)$ & $(10)$ & $(1.604)$ & $(902.5)$ \\
& & & & & & & &
\end{tabular}

${ }^{\dagger}$ EIS fitting data corresponding to MAPE is given within the brackets for each concentration and circuit components. 
showed the same phenomenon in which the increasing concentration of PE increased the $R_{\mathrm{ct}}$ value. This type of circuit model occurs when there is a more than one electrode processes occurring at the electrode electrolyte interface. The $C_{1}$ and $C_{2}$ have evolved may be due to the presence of charge compounds present in the PE i.e., the electrolyte and the charged surface on the electrode which are separated by the interface $C_{1}$ and $C_{2}$. The increase in the $C_{1}$ and $C_{2}$ may be attributed as the interface is more charged in which the phytochemicals constituents bind onto the DNA surface through which the electron transfer would take place more. As can be seen the $\mathrm{R}_{1}$ increase may be due to the PE molecules intercalating DNA or in other words the ROS species getting oxidized at the DNA surface is difficult and is also arduous getting the reduced ROS species out of the DNA. The PE molecules act like adsorbed molecules inside the DNA cavities and it does not require any electrochemical activation energy to get reduced inside the DNA. This results in surplus anions production at the DNA surface due to the reduction of $\mathrm{PE}$ molecules or ROS leading to the formation of huge double layer capacitor. The variations in capacitances are due to the reduced PE molecules which release anion radicals leading to the imbalance of capacitance. The association constant from equation (1) was found to be $1.76 \times 10^{-4}$ and $1.98 \times 10^{-3} \mu \mathrm{mol} \mathrm{dm}^{-3}$ for SAPE and MAPE respectively. The linear regression equation [Fig. 3(c)] is as follows -

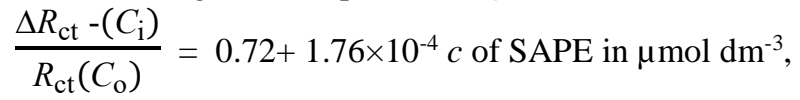

$R=0.966$

$\frac{\Delta R_{\mathrm{ct}}-\left(C_{\mathrm{i}}\right)}{R_{\mathrm{ct}}\left(C_{\mathrm{o}}\right)}=-7.31+1.98 \times 10^{-3} c$ of MAPE in $\mu \mathrm{mol} \mathrm{dm} \mathrm{dm}^{-3}$, $R=0.975$

From the impedimetric analysis it is found that the PE molecules have intercalation property in all the three different potential studied.

The limit of detection at a signal to noise ratio of $3 \sigma$ is 0. 22 and $0.29 \mu \mathrm{mol} \mathrm{dm}^{-3} \mathrm{~mL}^{-1}$ for SAPE and MAPE respectively. The limit of quantification was found to be 0.68 and $0.88 \mu \mathrm{mol} \mathrm{dm}{ }^{-3} \mathrm{~mL}^{-1}$ for SAPE and MAPE. The results can be interpreted as the PE molecules bind to DNA there is an oxidation of guanine peak leading to decrease in the peak current. The binding constant was calculated using a formula [47] -

$\log \left(\frac{1}{[\mathrm{PE}]}\right)=\log \left(K_{\mathrm{f}}\right)+\log \left(\frac{I_{\mathrm{p}}}{I_{\mathrm{p}}^{\mathrm{o}}-I_{\mathrm{p}}}\right)$

Where $K_{\mathrm{f}}$ is the formation constant, $I_{\mathrm{p}}{ }^{\circ}$ and $I_{\mathrm{p}}$ are the peak currents of without addition of $\mathrm{PE}$ and with addition of $\mathrm{PE}$ respectively. By substituting the values the binding constant or formation constant $K_{\mathrm{f}}$ was found to be $4.310 \times 10^{-6} \mu \mathrm{mol} \mathrm{dm}{ }^{-3}$ and $4.717 \times 10^{-4} \mu \mathrm{mol} \mathrm{dm}^{-3}$ for SAPE and MAPE.

The dose response curve was plotted against log 10 concentration of PE vs current response and by fitting the sigmoidal curve with origin software the following readings were recorded, $R^{2}-0.9932, \mathrm{IC}_{50}$ of $9.51 \times 10^{-2} \mu \mathrm{g}$ $\mathrm{mL}^{-1}$ for SAPE and $R^{2}-0.9994, \mathrm{IC}_{50}$ of $1.17 \times 10^{-2} \mu \mathrm{g} \mathrm{mL}^{-1}$ for MAPE.

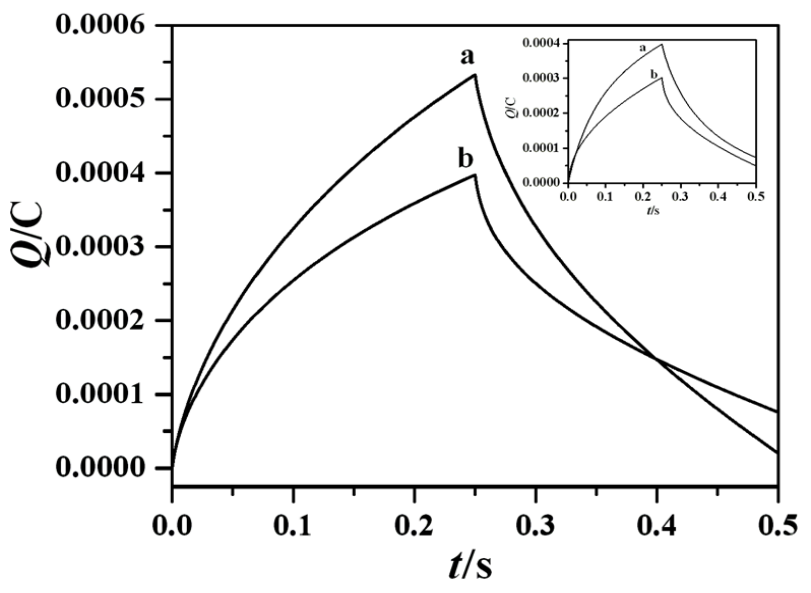

Fig. 4. Chronocoulometric curves for (a) Gr/PAH/NT-G/PPy/DNA electrode (b) Gr/PAH/NT-G/PPy/DNA electrode in presence of $5 \mu \mathrm{mol}$ $\mathrm{dm}^{-3} \mathrm{SAPE}$. Inset- shows chronocoulometric curves for (a) modified electrode and (b) Gr/PAH/NT-G/PPy/DNA electrode in presence of 5 $\mu \mathrm{mol} \mathrm{dm}^{-3} \mathrm{MAPE}$
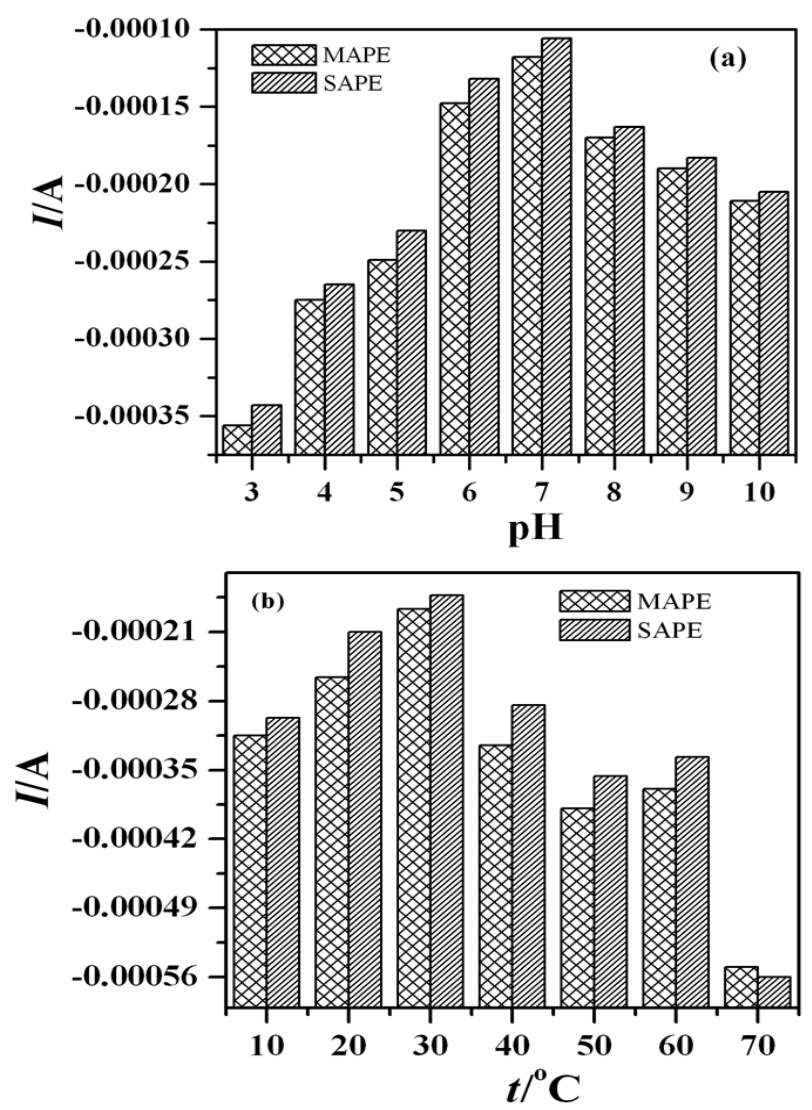

Fig. 5. (a) Effect of $\mathrm{pH}$ on the response Gr/PAH/NT-G/PPy/DNA electrode towards $2 \mu \mathrm{mol} \mathrm{dm}{ }^{-3} \mathrm{SAPE}$ and inset for MAPE, (b) Effect of on the temperature response of $\mathrm{Gr} / \mathrm{PAH} / \mathrm{NT}-\mathrm{G} / \mathrm{PPy} / \mathrm{DNA}$ electrode towards $2 \mu \mathrm{M}$ SAPE and inset for MAPE.

Chronocoulometric (CC) is a widely used electrochemical technique used for the measurement of charge as a function of time. There are various applications 
of CC in electrochemistry, such as measurement of surface area, to study the kinetics behind heterogeneous electron transfer reactions and chemical reactions [48]. In this text, it is used to determine the amount of PE adsorption onto the Gr/PAH/NT-G/ PPy electrode surface. Fig. 4 shows the $\mathrm{CC}$ of $\mathrm{Gr} / \mathrm{PAH} / \mathrm{NT}-\mathrm{G} / \mathrm{PPy}$ electrode at $50 \mu \mathrm{mol} \mathrm{\textrm {dm } ^ { - 3 }}$ SAPE, with the potential window of $0.3-1.2 \mathrm{~V}$ with a double potential CC and pulse width of $0.25 \mathrm{~s}$. While the Fig. 4 inset shows the CC for MAPE. The diffusion coefficient $\mathrm{D}$ and $\mathrm{Q}_{\mathrm{ads}}$ of PE onto the electrode surface was calculated by the formula [49] -

$$
\mathrm{Q}=\frac{2 \mathrm{n} F A c D t^{1 / 2}}{\pi^{1 / 2}}+\mathrm{Q}_{\mathrm{dl}}+\mathrm{Q}_{\mathrm{ads}}
$$

Where $Q_{\mathrm{dl}}$ is the double layer charge, $Q_{\mathrm{ads}}$ is the faradic charge due to the interaction of the PE to DNA. From the plot of $Q$ vs $t^{1 / 2}$, the values of $D$ (slope) $\mathrm{Q}_{\text {ads }}$ (intercept) can be obtained. The values of $Q_{\text {ads }}$ for SAPE is $7.71 \times 10^{-4}$ and $5.15 \times 10^{-5}$ for MAPE, A is area of the electrode which is $0.28 \mathrm{~cm}^{2}, c$ is the concentration of the $\mathrm{PE}-0.5 \mu \mathrm{mol} \mathrm{dm}{ }^{-3}$, $D$ was calculated to be $1.26 \times 10^{-3} \mathrm{~mol} \mathrm{~s}^{-1}$ (SAPE) and $1.7 \times 10^{-6} \mathrm{~mol} \mathrm{~s}^{-1}$ (MAPE). The surface characterization was calculated from the equation -

$\Gamma_{\mathrm{s}}=\frac{Q_{\mathrm{ads}}}{\mathrm{n} F A}$

The $\Gamma_{\mathrm{s}}$ for SAPE and MAPE was found to be $2.85 \times 10^{-}$ ${ }^{8} \mathrm{~mol} \mathrm{~cm}^{-2}$ and $1.9 \times 10^{-9} \mathrm{~mol} \mathrm{~cm} \mathrm{~cm}^{-2}$ respectively.

Fig. 5 (a) illustrates the $\mathrm{pH}$ effect on DNA biosensor response towards the SAPE and MAPE. DPV studies were carried out at increasing $\mathrm{pH}$ with a constant concentration of $2 \mu \mathrm{mol} \mathrm{dm}{ }^{-3}$ PE. The DPV peak current increased linearly from $\mathrm{pH} 4$ to $\mathrm{pH} \mathrm{7,} \mathrm{whereas} \mathrm{there} \mathrm{was} \mathrm{less} \mathrm{effect}$ of $\mathrm{PE}$ in $\mathrm{pH}$ 3. Then the current response declined when there is a further increase in $\mathrm{pH}$ from 7 to 10 . The DNA undergoes solubilization in acidic $\mathrm{pH}$ due to the hydrolysis of glycosidic bond of the DNA [31]. In basic pH the DNA will denature and form ssDNA. The current response solely depends on the DNA biosensor, where as the PE extract has the ability to intercalate or bind to the DNA in all the studied $\mathrm{pH}$.

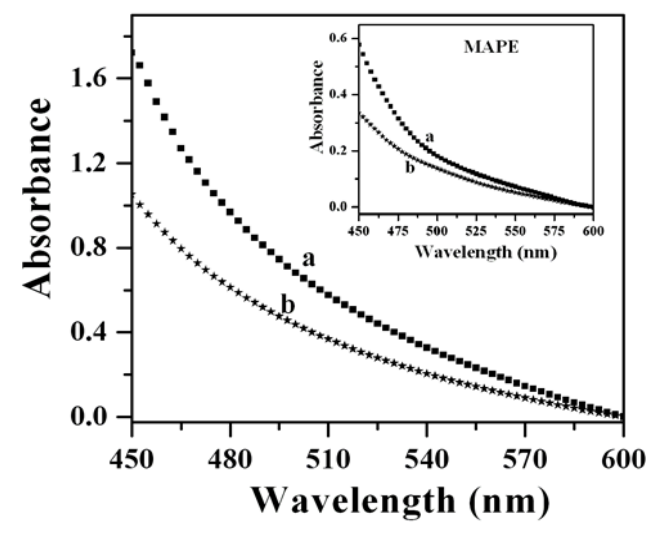

Fig. 6. Electronic spectra (UV-Vis) for (a) spectra of Calotropis procera (SAPE) alone (b) complex of Calotropis procera (SAPE) with DNA. Inset- spectra for MAPE (a) MAPE alone (b) complex of MAPE with DNA.
Changes in the current response of the DNA biosensor was studied at varying temperature from $10-70{ }^{\circ} \mathrm{C}$. The DNA biosensor current response was stabilized for each temperature until same background current is obtained. Then $2 \mu \mathrm{mol} \mathrm{dm}{ }^{-3} \mathrm{PE}$ was injected and the DPV peak current was recorded. As shown in Fig. 5 (b), the DNA biosensor has a linear increase in peak current up to $30^{\circ} \mathrm{C}$, and decreased when there is an increase in temperature. Note the Fig. shown is the current response of the DNA in presence of PE. The stabilized peak current decreased in presence of the PE indicating the ability of PE to intercalate the DNA. From these results the $\mathrm{T}_{\mathrm{m}}$ is midpoint of sigmodial curve was found to be $32.4{ }^{\circ} \mathrm{C}$. As a standard method, to contrast and to show righteousness of the electrochemical methods to detect the intercalation effect we have employed UV-Vis spectroscopy. The drug molecule interaction with DNA leads to complex configuration which results in structural alteration of DNA and stifles the physiological processes. This is a one of the characteristic feature of drugs to suppress the cancer cells or to destroy infected tissue. The unification of the drug and DNA possesses an impact on the absorption and emission properties [50] which can be examined significantly by spectrophotometric and spectrofluorometric methods [51]. The readings were recorded for the PE $5 \mu \mathrm{mol} \mathrm{dm}{ }^{-3}$ (SAPE \& MAPE) in wavelength range from 460- $600 \mathrm{~nm}$ in presence and absence of 5 ppm DNA and are as shown in Fig. 6. The interaction of PE with DNA decreased the absorbance indicating hypochromocity. This effect indicates the strong interacting of PE with DNA. The interaction may be surface specific interaction or minor grove interaction. The binding constant was calculated using formula [47]

$\frac{A_{0}}{A-A_{0}}=\frac{\varepsilon_{\mathrm{f}}}{\varepsilon_{\mathrm{b}}-\varepsilon_{\mathrm{f}}}+\frac{\varepsilon_{\mathrm{f}}}{\varepsilon_{\mathrm{b}}-\varepsilon_{\mathrm{f}}} \frac{1}{K_{\mathrm{f}}[\mathrm{DNA}]}$

where ' $\mathrm{A}_{\mathrm{o}}$ ' is absorbance of PE and ' $\mathrm{A}$ ' absorbance of PEDNA complex. ' $\varepsilon_{\mathrm{f}}$ ' and ' $\varepsilon_{\mathrm{b}}$ ' is the molar extinction coefficient of PE alone and PE bound to DNA respectively. The $K_{\mathrm{f}}$ was found to be for $4.91 \times 10^{-1} \mu \mathrm{mol} \mathrm{dm} \mathrm{dm}^{-3}$ and $4.55 \times 10^{-1} \mu \mathrm{mol} \mathrm{dm}{ }^{-3}$ for SAPE and MAPE.

\section{Conclusion}

The increasing death rate in cancer needs to be considered and development of anticancer drugs is growing field in modern research. The phytochemical compounds of plants can be screened and used as drugs. The conventional modes of extraction are time consuming instead the modern microwave assisted extraction can also be utilized. In this work we have employed microwave oven for the extraction process of plant phytochemicals and compared the characteristics of the extract with the conventional soxhlet apparatus extract towards DNA biosensor. From the Folin ciocalteau spectrophotometric analysis Calotropis procera plant extract was shown to contain a high amount of polyphenols. The TPC present in the sample of $20 \mu \mathrm{L}$ of SAPE and MAPE was found to be 500 $\mathrm{mg}$ and $475 \mathrm{mg}$ GAE/L respectively. The intercalating 
properties of the PE with DNA biosensor was analyzed used electrochemical impedance spectroscopy. The binding constant was calculated and further, we compared the electrochemical method with UV- the most accepted technique used to analyze the intercalating properties. The linear range was $1 \mu \mathrm{mol} \mathrm{dm}$ to $250 \mu \mathrm{mol} \mathrm{dm}{ }^{-3}$ with $\mathrm{T}_{\mathrm{m}}$ value of $32.4{ }^{\circ} \mathrm{C}$. Thus, our proposed electrochemical analysis to pre-screen the active substances for cancer is promising technique in aid to reduce the time consumed in screening. Moreover, the microwave assisted extraction can also be utilized to increase the rate of extraction compared to the conventional soxhlet extraction. Finally, Calotropis procera have potential to use against cancer.

\section{Acknowledgements}

The authors gratefully acknowledge the financial support from Department of Atomic Energy - Board of Research in Nuclear Sciences, Government of India. We thank Sri. A.V.S. Murthy, honorary secretary, Rashtreeya Sikshana Samiti Trust, Bangalore and Dr. Snehalata Nadiger, Principal, N.M.K.R.V. College for Women, Bangalore for their continuous support and encouragement.

\section{References}

1. David A. Karnofsky, CA Cancer J Clin, 1968, 18, 232

2. Yola, M. L.; Ozaltin, N.; Hacettepe Univ J Fac Pharm., 2012, 32,16

3. Wang, Q.; Wang, X.; Yu, Z.; Yuan, X.; Jiao, K.; Int. J. Electrochem. Sci., 2011, 6, 5470

4. Ravera, M.; Bagni, G.; Mascini, M.; Osella, D.; Bioinorg Chem appl 2007, 2007, 1

5. Lucarelli, F.; Autheir, L.; Bagni, G.; Marrazza, G.; Baussant, T.; Aas, E.; Mascini, M.; Anal. Lett. 2003, 36, 1887

6. Carter,T.M.; Rodriguez, M.; Bard, A.J.; J Am Chem Soc., 1989, 111, 8901.

7. Erdem, A.; Karadeniz, H.; Caliskan, A.; Electroanal., 2009, 21, 464.

8. Karadeniz, H.; Gulmez, B.; Sahinci, F.; Erdem, A.; Kaya, G. I.; Unver, N.; Kivcak B.; Ozsoz, M., J. Pharmaceut. Biomed., 2003, 33, 295.

9. Oliveira-Brett, A. M.; Macedo, T. R. A.; Raimundo, D.; Marques, M. H.; Serrano, S. H. P., Biosens. Bioelectron., 1998, 13, 861.

10. Fojta, M.; Havran, L.; Fulneckova, J.; Kubicarova, T., Electroanal., 2000, $12,926$.

11. Istanbullu, H.; Karadeniz, H.; Erciyas, E.; Erdem, A., Turk J Chem., 2016, 201,1

12. Nowicka, A.M.; Zabost, E.; Donten, M.; Mazerska, Z.; Stojek, Z., Anal. Bioanal. Chem., 2007, 389, 1931.

13. Wanga, H.; Khorb, T.O.; Shub, L.; Sub, Z.; Fuentesb, F.; Leeb, J.H.; Tony Kong, A.N., Anticancer Agents Med Chem., 2012, 12, 1281

14. Bachrach, Z.Y., Acta Fac. med. Naiss., 2012, 29, 117.

15. El-Alfy, T.S.; Ezzat, S.M.; Hegazy. A. K.; Amer, A.M.; Kamel, G. M., Pharmacogn Mag., 2011, 7, 109.

16. Bachmeier, B.E.; Mirisola, V.; Romeo, F.; Generoso, L.; Esposito, A.; Delleva, R.; Blengio, F.; Killian, P.H.; Albini, A.; Pfeffer, U., Cell Physiol Biochem. 2010, 26, 471.

17. Senft, C.; Polacin, M.; Priester, M.; Seifert, V.; Kogel, D.; Weissenberger, J., BMC Cancer, 2010, 10, 491.

18. Nalini, S.; Nandini, S.; Suresh, G. S.; Melo, J. S.; Neelagund, S. E.; NaveenKumar, H. N.; Sanetuntikul, J.; Shanmugam S.; Adv. Mater. Lett. 2016, 8, 100

19. Sharma, P.; Sharma, J.D.; Fitoterapia, 2000, 71, 77.

20. Bhaskar, V.H; Ajay, S. S.; Jordan j. biol., 2009, 2, 177

21. Dai, J.; Mumper, R.J.; Molecules 2010, 15, 7313.

22. Srinivas Rao, K.; Keshar, N.K.; Ravikumar, B.V.V.; Ind J Pharm Edu Res, 2012, 46, 228.

23. Lisdat, F.; Schäfer, D.; Anal. Bioanal. Chem. 2008, 391, 1555.

24. Macdonald, J.R.; Ann Biomed Eng 1987, 20, 289

25. Zou, Z.; Kai, J.; Rust, M. J.; Han, J.; Ahn, C. H.; Sens Actuators A Phys, 2007, 136, 518

26. Iijima, S.; Nature 1991, 354, 56

27. Elhissi, A. M. A.; Ahmed, W.; Ul Hassan, I.; J. drug deliv. 2012, 2012,1
28. Li, Y.; Zhou, W.; Wang, H.; Xie, L.; Liang, Y.; Wei, F.; Idrobo, J. C.; Pennycook, S.J.; Dai, H., Nat Nano, 2012, 7, 394

29. Arami, H.; Mazlomi, M.; Khalifehzadeh, R.; Hojjati, S.; Sadrnezhadeh, S.K.; Mater Lett, 2007, 61, 4412

30. Mogi, I.; Kamiko, M.; Bull. Chem. Soc. Jpn. 1996, 69, 1889

31. Moghaddam, A.B.; Nazari, T.; Badraghi, J.; Kazemzad, M.; Int J Electrochem Sci, 2009, 4, 247

32. Li, C. M.; Sun, C.Q.; Chen, W.; Pan, L.; Surf Coating Tech., 2005, 198, 474.

33. David, M.; Bharath Kumar, R.; Bhavani, M.; Int. Res. J. Pharm., 2013, 4, 250.

34. Kawo, A.H.; Mustapha, A.; Abdullahi, B.A.; Rogo, L.D.; Gaiya, Z.A.; Kumurya, A.S., Bajopas, 2009, 2, 34

35. Lodhi, G.; Hemant Kumar Singh, Pant, K. K.; Hussain, Z., Acta Pharm. 2009, 59, 89

36. Patil, K.S; Mamatha, G. C.; Chaturvedi, S. C., J Nat Remedies, 2007, 7, 189.

37. Rama Prabha, M.; Vasantha, K., J. appl. pharm. sci. 2011, 1, 136

38. Wu, L.; Chu, O. M.; Li, H. W.; Bot. Bull. of Acad. Sinica 1966, 8, 91.

39. Sikorska, M.; Matlawsk, I.; Acta Pol Pharm-Drug Res 2008, 65, 467.

40. Adefuye, A.O., Ndip, R.N.; Pharmacogn Mag 2013, 33, 45.

41. Palchaudhuri, R.; Hergenrother, P.J.; Current Opinion in Biotechnology 2007, 18, 497.

42. Dhivya, R.; Manimegalai, K., J. of Pharmacogn. Phytochem. 2013, $2,28$.

43. Mathura, R.; Gupta, S.K.; Mathur, S.R.; Velpandian, T., 2011, 55, 5

44. Brett, C.M.A.; Brett, A.M.O.; Serrano, S. H.P.; Electrochim. Acta 1999, 44,4233

45. Arya, S.K.; Bhansali, S.; Biosensors Journal 2012, 1,1

46. Perveen, F.; Shah, A.; Ahmed, S.; Latif Ansari, F.; Kalssom, S.; Mehboob, S.; Int. R. J. Pharm. 2011, 1, 1

47. Fragkou, V.; Ge, Y.; Steiner, G.; Freeman, D.; Bartetzko, N.; Turner, A. P.F.; Int. J. Electrochem. Sci. 2012, 7, 6214.

48. Li, M.; Jing, L.; Electrochim. Acta 2007, 52, 3250.

49. Ulianas, A.; Heng, L.Y.; Abu Hanifah, S.; Ling, T. L.; Sens. 2012, 12, 5445.

50. Cantor, C. R.; Schimmel, P. R., Biophysical Chemrstry part 2; W. H. Freeman and Co., San Francisco 1980

51. Ihmels, H.; Faulhaber, K.; Vedaldi, D.; Acqua, F. D.; Viola, G.; Photochem. Photobiol. 2005, 81, 1107.

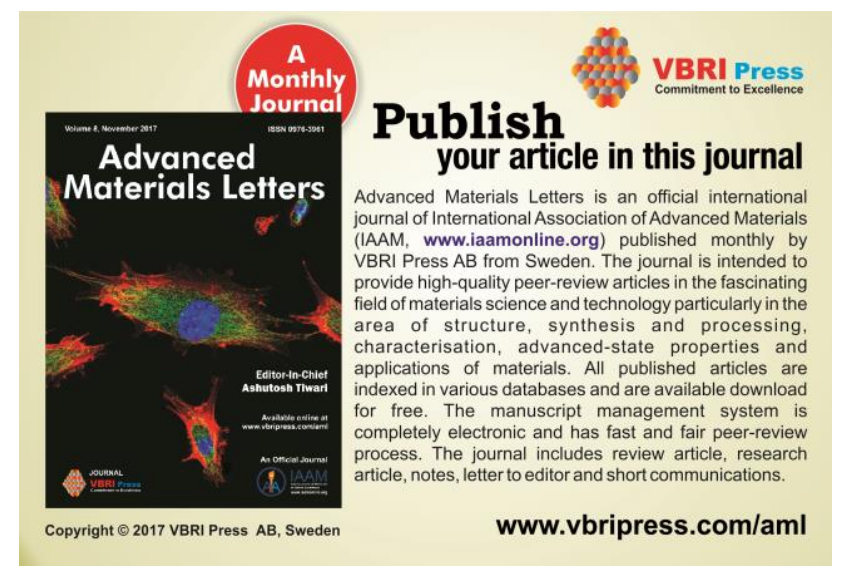

